\title{
The Executive Mechanism of Rastin Profit and Loss Sharing (PLS) Banking
}

\author{
Bijan Bidabad ${ }^{1}$ \\ Mahmoud Allahyarifard ${ }^{2}$
}

\begin{abstract}
Despite the interest of bankers for using Profit and Loss Sharing (PLS) ${ }^{3}$ banking for the last decades, it has not prevailed yet executively. The existence of different definitions of Riba, absence of appropriate operational, supervisory, and managing mechanism on PLS are some reasons that haven't allowed this kind of banking to be practiced yet. Here, we are going to introduce a practical method for Profit and Loss Sharing (PLS) banking to overcome these problems. In this bank, the basis for determination of interest rate of loans is real economy return rate. The bank operates as an intermediary, who gets commission fee, collects saving resources and as an attorney or legal representative of the depositor, allocates them to investment projects, and supervises the detailed operation of the contractor. The yields of the investment will transfer to resources owners who are depositors whatever profit or losses. The PLS banking is a banking system with newly defined instruments of Mosharaka and Pazireh that not only stabilizes the financial and economic markets by preventing the banks, loanees /entrepreneurs and design, construction and contractor sectors in the economy from bankruptcy during crisis periods and volatile markets, but also makes the banks as an international firm which perform similar jobs as stock exchange markets for transactions of PLS products certificates through a secondary certificate market on virtual internet space. Depositors will earn more stabilized benefits too.In this designed method, a trustee (Amin) is a unit who supervise the contractor/entrepreneur operations on behalf of the bank for being honesty in carrying out the project, controlling on executive operations along with announced programs, resources allocation manner, and auditing financial statements.PLS banking will use new financial instruments and innovations such as Mosharaka (partnership) Certificates for projects with specific ends and Pazireh (Subscripted) Certificates for endless (productive) projects. Establishing of secondary exchange market for the transaction of certificates, and various insurance services will play important roles for activating and increasing the efficiency of newly established virtual markets.All of the activities in this method will be done on the basis of compiled instructions. The framework and the organization of the PLS banking have been analyzed in forms of required committees, units, and departments tailored for this type of Non-Usury Bank (NubankCo.) definition.
\end{abstract}

Keywords: PLS, Riba, Financial management, Islamic banking

JEL:L86 ,L87 ,G21 ,G24

\section{Introduction}

Many countries around the world have been doing huge tasks for the fulfillment of Islamic banking. The low-risk characteristic in this kind of banking has caused a tendency to keep getting this kind of banking method even in many non-Muslim countries besides Muslim countries in order to get rid of risks like American, European and some Asian countries. Based on IMF reports, the average growth of the Islamic banking has been estimated about $10 \%-$

\footnotetext{
1 - (B.A., M.Sc., Ph.D., Post-Doc.) Professor of economics, Islamic Azad University, Tehran, Iran. http://www.bidabad.com/ Bijan@bidabad.com

Tel: +98.21 .88360810 Fax: +98.21 .88360811$

2- Expert of R\&D Dept., Bank Melli Iran ,Office: +98.21.88916343, Fax: 98.21.88905436, Allahyarifard@ gmail.com

3 - This invention has been protected by US patent law under the application number: US 12/588,188
} 
$15 \%$ each year in the last decade, and it will be forecasted in the next years with the same growth as before. Despite the huge growth, Profit and Loss Sharing (PLS) has not been developed satisfactorily, and it usually has been mingled with usuric banking because of being so new in view of its performance and operational mechanism. Even its financial instruments as Profit and Loss Certificate or Investment Deposit Certificate had been introduced at the end of the 1990s were forgotten later. Generally, the main reasons for unsuccessful in this kind of banking method come from the following causes:

- Different jurisprudential understanding of usury by different Islamic religious sects.

- Lack of supervisory and managing processes on loanee's financial and executive operations.

The absence of appropriate executive processes in operations, supervision, and management sides consistent with profit and loss sharing requirements, and incompatibility of bank's organizational infrastructures are significant factors to unfulfilled ideal theories of Islamic banking. Because the banks have not been organized and established for supervising on details of investment operations as a supervisory organization. Essentially these organizations cannot tackle this kind of functioning. Therefore, practically, the interest rate comes into PLS banking calculations by any definition or similarity. However, though the manifestation of Riba is not seen in it, the interest rate would be recognized by scrutinizing the interior of the financial operations ${ }^{4}$. On the other hand, jurisprudential deductions of different Islamic sects are not similar, so this point caused the Islamic banks around the world generating many nonusuric products that the most of them are compatible with current usuric banking products and moved into the usuric realm. Even in Iran, in spite of existing more external coordination and more unanimous than other countries, the result was similar as well. However, the unanimity in early 1360s Hejri during approving non-usuric banking law has also digressed thereafter. Therefore, first, the general solution for fulfillment of pure Islamic banking requires that the subject will be analyzed and considered from the base.

The main purpose of this paper is to consider the practical model for PLS banking and the present appropriate method for performing real non-usury banking accompanying with necessary provisions for applying modern financial instrument that will be provided based on information technology. Actually, the fulfillment of PLS banking will cause increasing stability of market transactions and equal distribution of the revenues of investment activities and decreasing the investment risk.

On the other side, the proposed financial instrument (participation Certificates and Subscripted Certificates) have ability to be bought and sold on the Internet through Internet Banking and anyone having a bank account with the approved ID information is able to buy and sell these financial assets around the world.

\footnotetext{
${ }^{4}$ For instance see:

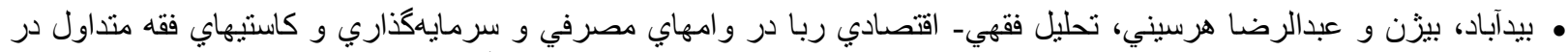

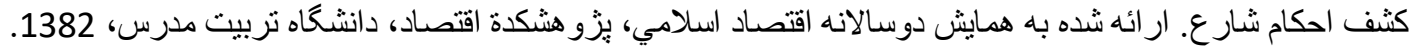
http://www.bidabad.com/doc/reba9.html

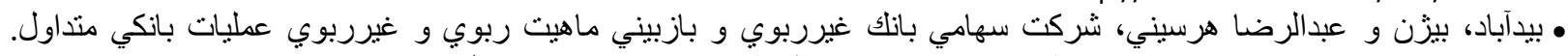

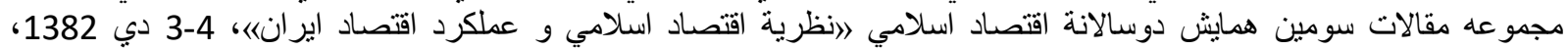

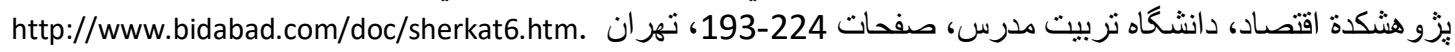

- Bidabad, Bijan and Mahmoud Allahyarifard, "Implementing IT to fulfill the profit and loss sharing mechanism", Islamic Finance News (IFN) Journals, Vol. 3, Issue 3, $6^{\text {th }}$ February 2006. http://www.bidabad.com/doc/summary-pls-it-1.html

- Bidabad, Bijan and Mahmoud Allahyarifard, "IT role in fulfillment of profit and loss sharing", Proceeding of The $3^{\text {rd }}$ International Islamic Banking and Finance Conference, Monash University, Kuala Lumpur, Malaysia, $16^{\text {th }}$ and $17^{\text {th }}$ November 2005. http://www.bidabad.com/doc/english-pls-5.pdf

- Bidabad, Bijan, Economic-juristic analysis of usury in consumption and investment loans and contemporary jurisprudence shortages in exploring legislator commandments. Proceeding of the $2^{\text {nd }}$ International Islamic Banking Conference. Monash University of Malaysia. 9-10 September 2004. Reprinted in: National Interest, Journal of the Center for Strategic Research, Vol. 2, No. 1, winter 2006, pp. 72-90. Tehran, Iran. http://www.bidabad.com/doc/reba-english-4.html

- Bidabad, Bijan, Non-Usury Bank Corporation (NUBankCo), The Solution to Islamic banking, Proceeding of the $3^{\text {rd }}$ International Islamic Banking and Finance Conference, Monash University, KL, Malaysia, 16-17 November, 2005. http://www.bidabad.com/doc/nubankco.html
} 


\section{The Experience of the PLS Banking}

The prohibition of Riba (Usury) and Profit and Loss Sharing (PLS) subject has a long history, and the subject returns to Torah and historical religious texts before Islam. The PLS was developed with Islam growth and nowadays have been paying attention as an important financial instrument, and PLS is recognized as a modern successful financing instrument ${ }^{5}$. Mudarabah and Musharakah are two financial instruments based on the PLS method that eliminates the fixed rate of return (interest rate) from financial operations and participate financers into the profit and loss of investment activities. ${ }^{6}$

The various conceptual definitions have been presented on PLS by some Islamic economists, and every one of them has touched it as follows:

- $\quad$ PLS is a contractual arrangement between two or more transacting parties, which allows them to pool their resources to invest in a project to share in profit and loss" (Humayon, Presley, 2000) ${ }^{7}$.

- "Under the PLS paradigm, the assets and liabilities of Islamic banks are integrated in the sense that borrowers share profits and losses with the banks, which in turn share profits and losses with the depositors" (Chong, Liu, 2007). ${ }^{8}$

- $\quad$ "PLS leads to a more efficient allocation of capital because the return on capital and its allocation depend on the productivity and viability of the project" (Khan, 1986) ${ }^{9}$.

Chong Liu (2007) studies on Malaysia Islamic Banking in large Islamic banking of Malaysia of capital and insurance markets (World Bank, 2006) ${ }^{10}$ show the following consequences:

- Despite the PLS banking focuses on the Islamic banking, the Islamic banking of Malaysia has not been successful in fulfilling PLS, and adoption of PLS paradigm has been much slower on the asset side than on liability side. Based on this study, on the asset side, only 5\% of Islamic banks and financing is based on the PLS paradigm of Mudarabah (profit-sharing) and Musharakah (joint venture) financing. Islamic bank financing in Malaysia, in practice, is still based largely on non-PLS manners of financing that are not allowed in the Shariah (Islamic law) and obeys the spirit of the usury. On the liability side, however, Mudarabah (profit-sharing) deposits, which account for $70 \%$ of total Islamic deposits, are more dominant.

- The rate of return in Malaysia PLS banking is less than the rate of return in conventional banking, so the rate of return of this kind of deposits depends on conventional banking rate of return but not vice versa.

The same problems are observed in Iran. Generally, PLS banking in Iran's Islamic banking did not develop because of similar reasons. Focusing on Iran banks balance sheets items indicates that at each side of assets and liabilities, the proportion of Musharakah products in comparison with other products was at minimum before the compulsory decision for decreasing the interest rate by the government. In other words, the Musharakah contractions were at the minimum, and the exchange contractions had the maximum share on monetary resources. Furthermore, the rates of return of this kind of investments are determined on the basis of expected return (and not actual return). In the debit side, in a majority of cases, the depositors receive a return on the basis of Vekalat contraction with a specified rate determined by the central bank of Iran. During the last decade by emerging private banks and increasing competition, they used to pay $1 \%$ or $2 \%$ more than in part (promised) payments as the final rate for settlement with

\footnotetext{
5 Rammal, H. G. (2003) 'Mudaraba in Islamic finance: principles and application', Business Journal for Entrepreneurs, Vol.4, pp.105-112. http://www.westga.edu/ bquest/2004/musharaka.htm

"Hussain Gulzar Rammal and Ralf Zurbruegg, "Awareness of Islamic banking products among Muslims: The case of Australia", Journal of Financial Services Marketing (2007) 12, 65-74. doi:10.1057/palgrave.fsm.4760060, http://www.palgrave-journals.com/fsm/journal/v12/n1/full/4760060a.html\#bib24

7 Humayon A. Dar and John R. Presley (2000), "Lack of Profit Loss Sharing in Islamic Banking: Management and Control Imbalances", Loughborough University,Department of Economics, Economic Research Paper No. 00/24, http://www.lut.ac.uk/departments/ec/Reasearchpapers/2000/00-24/erp00-24.pdf

${ }^{8}$ Chong, B.S., Liu, M.H, 2007, "Islamic Banking: Interest-Free or Interest -Based", http://www.efmaefm.org/0EFMAMEETINGS/EFMA\%20ANNUAL\%20MEETINGS/2007-Vienna/Papers/0019.pdf

${ }^{9}$ Khan, M.S., 1986. Islamic interest-free banking. IMF Staff Papers 33, 1-27. Refer to the above address

${ }^{10}$ World Bank, 2006. Country brief report: Malaysia.

http://siteresources.worldbank.org/INTEAPHALFYEARLYUPDATE/Resources/550192-1143237132157/malaysiaMarch06.pdf
} 
the customers. Increasing government pressure on banks for decreasing exchange contraction return rates to keep the banks with positive profit markup in recent years caused the banks to go toward the Musharakah contractions. However, the fulfillment of the PLS banking in the assets side of Iran banks is facing the following problems:

- Lack of specialist organizations and approaches for effective supervision on investment projects on the basis of the Musharakah contractions.

- $\quad$ Lack of IT capabilities for applying integrated systems in Islamic banking ${ }^{11}$.

- Lack of design of new financial instruments, and lack of effective capital market for financing as PLS banking.

\section{PLS Banking Architecture}

The foundation of the PLS banking is based on the keep getting benefit of economy real sector return for the whole participants of the economic activities. Therefore, the capital owners (shareholders), labor, services, and technology suppliers and operators should get benefit proportionally on the basis of their own portion and inputs. Fulfillment of this approach could be provided by the executive preparation of PLS banking. For designing PLS banking architecture, first of all, each party or entity and its functions should be explained precisely. In addition to the bank, depositor, entrepreneur (project handler and technical and executive knowledge owner) new organizational pillars are required for the practical structure of the PLS banking to be established to handle over special duties regarding the specific nature of partnership activities. In the new architecture, the functions of each unit will be different from what they are in conventional banking, though their names are called as same as conventional banking units.

Bank: The bank as an authorized agent on behalf of the depositors allocates the deposit resources of depositors to approved applicants of the credit facilities according to specific contracts and distribute the investment return as profit or loss consequences among the depositors, bank, and entrepreneur. The bank contractions with each party could be made on the basis of commission or profit and loss partnership. The bank as depositor's attorney or representative is obliged to protect the depositor's rights and must apply her complete own specialized powers for preserving depositor benefits.

Depositors: who is the supplier of financial resources, based on investment Joaleh contracts uses her financial resources to purchase certificates of participation (Mosharaka Certificate) for participation in Finitude projects or buy Certificates of Subscription (Pazireh Certificate) for participation in endless projects; in specific project or specific package of projects or profit and loss participation in the PLS bank branch, to participate in the profit and loss of the project (or financial product) according to her share.

Entrepreneur: is a legal entity that combines her own cash and non-liquid assets with the depositors' deposits as joint owners (spooling) and bank intermediary to establish a joint venture activity.

Trustee (Amin): is a unit who takes over the responsibility of supervising on the PLS process on behalf of the bank about the quality of carrying out the project, controlling practical operations in compare with approved documented entrepreneur plan, benchmarking, entrepreneur resources allocation and quality of optimum resources allocations etc by applying key indices and verifying entrepreneur financial statements.

Arbitration (Hakamiyat): takes over resolving the disputes and conflicts among the bank, entrepreneur, and depositors whose financial relationship is based on PLS banking. In the case of concordance of the parties, resolving of claim might be to a pre-approved third-party judicial person/entity that is acceptable for parties in the conflict.

Secondary Market: The secondary market is suggested for simplifying, progressing, and to make Mosharaka (partnership) and Pazireh (Subscripted) Certificates more attractive. Bank creates this facility that Mosharaka (partnership) and Pazireh (Subscripted) Certificates can be legally be sold and purchased in the secondary market on the internet.

\footnotetext{
${ }^{11}$ Bidabad, Bijan and Mahmoud Allahyarifard, "Implementing IT to fulfill the profit and loss sharing mechanism", Islamic Finance News (IFN) Journals, Vol. 3, Issue 3, 6th February 2006. http://www.bidabad.com/doc/summary-pls-it-1.html
} 
Consultants: The consultants take over the role of economic, financial, and technical assessments in PLS banking. The complexity of some projects in view of the applied technology, the use of hiring specialists in the area is doubtlessly inevitable.

\section{Interactions and relations in the PLS banking}

The relation between the essential pillars of PLS banking is shown in chart 1. Based on this method, apart from the bank is private or governmental, the interest rate of the bank's facility will be determined according to real investment return. Bank as fund intermediary gains wage or commission as attorney or agent of the depositor and the rest of the investment return will be paid back to depositors as profit or loss consequences. Accordingly, bank according to participatory investment based on general or special attorney contracts invests deposits collectively based on a diagnosis of the depositor (in product 1 and 2) or on her diagnosis (for product 3 ) in the desired projects/plan and distribute the investment outcomes among providing depositors.

In the first step of PLS operation, entrepreneur presents her proposal and required documents and feasibility study regarding economic, financial and technical aspects of his project/plan according to compiled instructions in PLS banking instruction set. The entrepreneur delivers all required official letters and documents to the bank according to related bank compiled instructions including budgeting, time schedule, size of necessary resources and resource allocation manner, qualification of carrying the project, phasing, quality management, reporting, project completion manner, specification of completed project quality... The bank in case of necessity when the project contains special, complex or high technology and the bank's specialists are not able to evaluate and make supervision on the project will outsource the project evaluation and supervision as well to other consultants for evaluation and/or supervision. The bank in case of positive evaluation on both entrepreneur and proposal will publicize the project to interested depositors for participating in depositors according to specified PLS banking products for financing the projects. The depositors would buy the Mosharaka (partnership) Certificates or the Pazireh (Subscripted) Certificates and donate deposits to the bank, and the bank allocates monetary resources to the suggested projects by empowering the entrepreneur to start the project. Trustee (Amin) supervises and controls the operations of the entrepreneur directly on behalf of the bank for the whole process. Obviously, reports of the trustee will be considered as the main criterion for next payments to an entrepreneur from the bank. After completing the project according to the related instructions and predefined PLS accounting formulas, the portion of profit or loss consequences and the bank commission/wage portion will be calculated by the accounting and auditing department. The portions of entrepreneur, depositors, and bank will be determined and are transferred to their accounts. In case of existence of any reports on the interruption of operations of the project from the trustee side, the amount of delaying losses will be computed and determined according to the related instructions.

\section{Chart 1: PLS Banking Pillars}

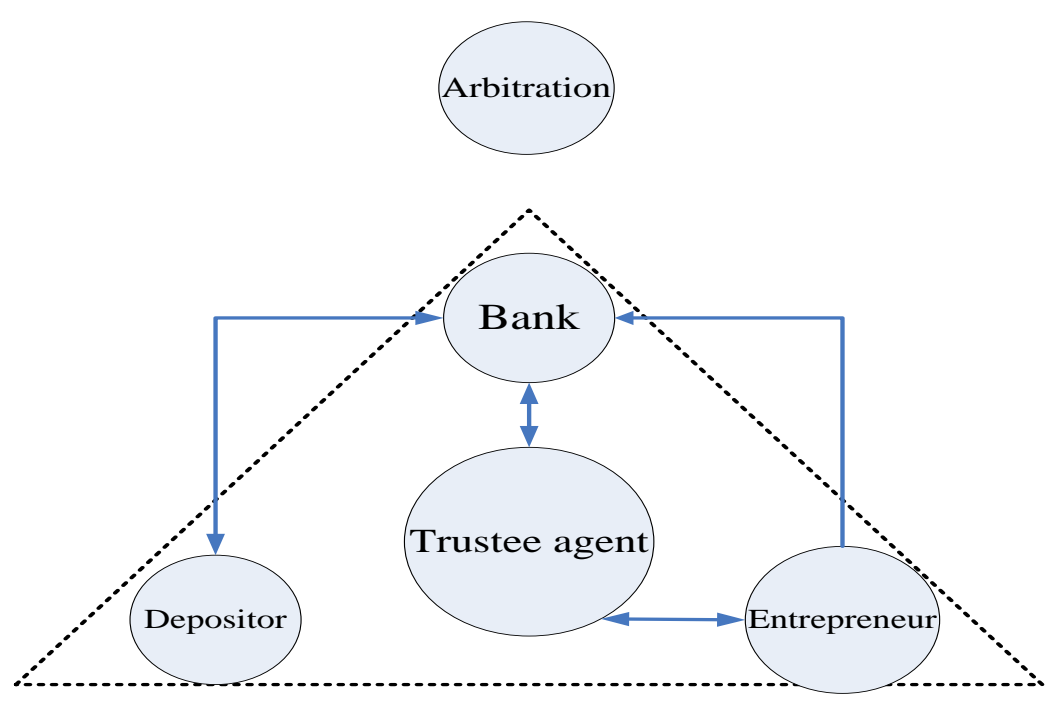


The PLS banking products as Mosharaka (partnership) and Pazireh (Subscripted) Certificates are issued by PLS bank under the central bank general approved PLS regulations ${ }^{12}$, and the Certificates will be supplied to the depositors. The depositors could sell them at the secondary market before the due settlement time in case of revoking to cancel their depositing activity. They can do this via the bank's electronic portal on internet or bank's transaction counters.

Insurance companies' collaborations to hedge the certificates have been observed in this kind of banking.

\section{Legal requirements}

Lack of executive experience necessary for this type of banking cause new regulations and the development of new guidelines. The first step should be in the form of necessary upstream regulations and rules to be issued by the central bank if there is a lack of regulations or guidelines within the banking industry for this kind of banking financial tools such as participation Certificates and Subscripted Certificates for their legal protections.

\section{Components}

Generally, the components of the PLS banking could be classified as the following items:

- Products and Services

* Finitude projects

$>$ Mosharaka (partnership) Certificates for profit and loss sharing on a special project.

> Mosharaka (partnership) Certificates for profit and loss sharing on a projects portfolio.

$>$ Mosharaka (partnership) Certificates for profit and loss sharing on a PLS bank.

* Endless projects

$>$ Pazireh (Subscripted) Certificates to shares

- Customer groups

* Depositors

$>$ Real entity

* Entrepreneurs

$>$ Legal entity

- Financial instruments

$>$ Legal entities (private, governmental)

* Insurance agents

* Portfolio management of Mosharaka (partnership) and Pazireh (Subscripted) Certificates.

$>$ Minimum risk and return

$>$ Middle risk and return

$>$ High risk and return

* Certificates insurance with avoidance from

$>$ Moral hazard

$>$ Adverse selection

$>$ Asymmetric information

* Executive insurance

$>$ Responsibility insurance

$>$ Project's place insurance

- Mechanism and specification of Mosharaka/Pazireh IT based transactional system

* Information system

- Buying/ selling of Mosharaka/Pazireh Certificates as remote

* 24x7

* Multi-languages

* Multi-currencies

12. Central bank supervises on PLS banking operations as legislator of monetary regulations. Approval and confirmation of required regulations in this kind of banking method and general regulations for issuance of PLS banking products might be allowed by central bank or other monetary authorities depending on different countries legal systems. 
- Contractions
* Integrated
* High secured
* Privacy

* Depositor

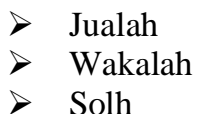

* Entrepreneur

$>$ Mosharaka

* Consultant (assessment, trusteeship)

$>$ Jualah

- Office infrastructures, organization

* PLS Strategy committee

* Interpretation and revising of PLS regulations and process specialist group

* PLS office including the following department

$>$ Legal department

$>$ Project evaluation, including the following specialist:

$\circ$ Economic

○ Financial

- Technical and engineering (Back office)

$>$ Auditing Department

$>$ Financial engineering management

$>$ Trustee (Amin)

$\circ$ Financial

- Technical and engineering

$\circ$ Legal

$>$ PLS branch (front office)

$>$ Information (consulting services)

$>$ Cashier

Mosharaka/Pazireh Certificates transactions

$>$ Others

- Typical contracts including:

* Contraction with entrepreneur

- Contraction with depositors

- Contraction with the trustee (Amin)

* Evaluation contraction

- Instructions

* Documents and required papers

* Entrepreneur ability reaching

* Justification reports

* Accounting and auditing

- Guarantees, collaterals, and inputs

* Banks returns

* The general condition of contraction

* Set out the contraction

* Standards and requirements for supervision

* Trustee (Amin) competency

* Entrepreneur reporting

* Mosharaka/Pazireh Certificates transactions

* Mosharaka/Pazireh Certificates swapping

* Time schedule variation

* New partnership

* Depositor cancellation

* Settlement

* Arbitration 


\section{* Force major}

\section{Instructions}

For fulfillment of the PLS banking, operational methods will be performed by the following compiled instructions:

1. Guarantees, collaterals, and capital brought: Depend on the entrepreneur classification (green and yellow groups) the collateral will be taken in different types of collaterals and guarantees for good performance. The input portion of the entrepreneur, including cash or non-cash in each category, is determined by this instruction.

2. Required documents for project evaluation: All the required financial and non-financial documents for project evaluation and legal and performance authorizations are determined by this instruction.

3. Entrepreneur reportings: The reports to the bank, trustee, inspector, or other controlling authorities are determined in this instruction.

4. Feasibility reports: The main purpose of this instruction is to organize and standardize the economic, technical and financial feasibility studies of the project till the affiliated departments can evaluate the mentioned documents according to the specified framework.

5. Arbitration (Hakam): The condition of referring conflicts among parties (depositors and entrepreneur with the bank) to a pre-accepted third person/s is determined in this instruction.

6. Force major: Coming up unexpected events for beneficiaries of the PLS banking are to be handled by this instruction.

7. Instruction for revocation of depositors to cancel her deposit before due date: Revocation of depositors to cancel her deposit for not carrying on the investment and the settlement manner for the cancelation by selling Mosharaka and Pazireh Certificates is specified in this instruction.

8. Time schedule and expense deviations: In case of coming up deviations, either in time schedules or expenses plan of the projects coming from either fault or delinquency of the entrepreneur or effect of inflation in calculation of costs of entrepreneur and also the manner of calculation of share of beneficiaries in these circumstances are specified in this instruction.

9. New partnership: In the case of extended financing of PLS projects, issuance of new Mosharaka and Pazireh Certificates would be according to this instruction.

10. To settle with an entrepreneur: The settlement terms and manner with the entrepreneur is specified in this instruction.

11. Pazireh Certificates swapping: To change Pazireh Certificates to shares and the related processes and valuation of shares are specified in this instruction.

12. Mosharaka and Pazireh Certificates transactions: The Mosharaka and Pazireh Certificates transactions on internet and establishment of the secondary market and market management are specified in this instruction.

13. The entrepreneur ability: Including the points regarding technical and financial capability and qualification classification of the entrepreneurs based on the different projects, collaterals types and guarantees for good performance, the fulfillment of obligations, the share of entrepreneur, entrepreneur partnership inputs and entrepreneur classification to three categories of green, yellow and read.

14. Trustee (Amin) competency: specification and competency of the trustee as supervisor agent to supervise the entrepreneur performance as real persons or legal entities are described in this instruction.

15. The standards and supervision obligations: This instruction takes over the whole obligations and required standards for supervisory processes.

16. General conditions of contraction: To regularize proper contractions and making contents of contracts obligatory and legally mandatory for each party in the PLS banking this instruction is to be used.

17. Contracts compilation: Typical compiled contracts of the bank with entrepreneur, depositors, the trustee (Amin) and consultants of the project have been brought in this instruction for each type of PLS banking products including finitude and endless projects.

18. Accounting and auditing: The requirements and obligations of the auditor, auditing process, financial statements of the entrepreneur's company, and documents verifying to confirm the accuracy of the operations of entrepreneur are cited in this instruction. 
19. Bank gains: Gains of the bank in all processes of primary and supplementary evaluations, supervisory services, the trustee (Amin), financial engineering, auditing, and the other services and also the bank's wages and commissions have been specified in this instruction.

\section{IT infrastructures}

Based on the previous researches ${ }^{13}$, one of the important reasons to not prevailing PLS banking is lack of integrated systems, which able the bank to connect whole producers of information resources together and every transaction will be traced and supervised through them. Therefore, for achieving the ideal PLS condition it is necessary to integrate different systems including Enterprise Resource Planning (ERP), and Islamic core banking containing other modules and subsystems like Customer Relationship Management (CRM), Supply Chain Management (SCM), Manufacture Executive System (MES), Human Resource Management (HRM), Business Process Reengineering (BPR), Workflow management (WFM). But this solution is for as an ideal PLS. Since integrated core banking necessities for this type of PLS banking is not available yet, so it is not possible to apply this integrated PLS banking as full automatic banking and leave this idea for the future extension of PLS.

The applied technology in this phase is a web-based secondary market portal for Mosharaka and Pazireh Certificates, which will be applicable through the internet connection and can be connected to the personal accounts in the bank. The individuals or the Certificate's owners become able to deal with these kinds of digital papers (certificates) through the internet-based communication networks. Therefore, these certificates as an asset can be negotiated and traded over the world on the internet. Generally, the PLS banking products specifications have been shown in table 1 . The attractiveness of the products will be increased through the internet-based transactions on the virtual secondary market on the internet.

\section{PLS Banking Products and Services}

According to table 1, the designed products and services in PLS banking are separated into two categories of finitude and endless projects. The bank will get a commission for supplying some financial management services such as making confidence among the depositors, supervision, financial engineering, project management, and also transparency in the whole PLS products to depositors.

- The finitude projects partnership: In this category of the PLS banking products, the investment return will be allocated and settled among the depositors, entrepreneur, and bank at the end of the fiscal year (for product type 3) or after the ending time when the project will be finished and sold - depending on type of project. The products used can be a special project or a basket of projects. The applied financial instruments in these products are Mosharaka Certificate so that after depositing of the depositor in a project immediately Mosharaka Certificate will be delivered to the depositors.

- The endless project's partnership: According to chart 2, the bank will subscribe to the shares in the form of issuing Pazireh (Subscripted) Certificates for financing an endless project. The Pazireh (Subscripted) Certificate is similar to Mosharaka (partnership products) Certificate and can be transacted at the secondary Certificate market. After ending the construction period and when the project is ready to start the exploitation period, the Pazireh Certificates will be transformed into the shares of the corporation. The whole subscriptions process, exchanging Pazireh Certificates to the share papers will be performed under the bank supervision, and decisively the project ownership will be assigned to the depositors through changing their Pazireh Certificates to the shares, and after this transformation, the depositors will become company shareholders.

The bank might do the whole transforming process through changing Pazireh Certificates owners to shareholders by establishing a new company (and not the entrepreneur constructing company) at the end of the construction period and at the beginning of exploitation period. The bank might sale the shares of the Pazireh Certificates owners in bidding, and after deducting the entrepreneur and the bank, portions pays cash to depositors.

\footnotetext{
13 Bidabad, Bijan and Mahmoud Allahyarifard, "Implementing IT to fulfill the profit and loss sharing mechanism", Islamic
} Finance News (IFN) Journals, Vol. 3, Issue 3, $6^{\text {th }}$ February 2006. http://www.bidabad.com/doc/summary-pls-it-1.html 
The Mosharaka and Pazireh Certificates

The two important financial instruments of PLS banking are The Mosharaka and Pazireh Certificates.

- Mosharaka Certificate is an anonymous (digital) paper that is issued with a specified nominal price for a specific duration (performance duration of the finitude investment project) by the branch of the PLS bank. The owners of the papers participate on investment return in proportion to nominal price and duration of being as a partner in the project, and the bank will earn commission in lieu of supplying capital management services to depositors that are offered by depositors for investing their money resources in the PLS banking products.

- Pazireh (Subscripted) Certificates is an anonymous (digital) paper is issued with specified nominal price and durations (performance duration of endless investment project up to the end of construction period) by the branch of the PLS bank. The owners of these papers will be the owner of the company of the project in the form of shareholders in proportion to their nominal price of their Certificate and duration of the partnership.

According to table 1, anonymity, transformability to others, transact ability in virtual secondary certificate market and in stock exchange markets, commission return of transactions for the bank (0.0005 from each transacted parties - seller and buyer), demand and supply (market mechanism) based price determination on internet secondary market, and final settlement with the final authenticated certificate owner are some of the attractive specifications for both Mosharaka and Pazireh Certificates. The main difference between Mosharaka and Pazireh Certificates is in finitude and endless nature of the projects. In the case of Mosharaka Certificate, the settlement process will be done at the end of the construction period by bidding and selling the project. In case of issuing Mosharaka Certificate for partnership in the PLS branch's profit (product type 3), the settlement process will be done at the end of the fiscal year when the PLS branch's financial statements are finalized. In the case of Pazireh Certificate, the bank undertakes to change Pazireh Certificates owners to shareholders of the investment project, and there is no responsibility for PLS bank to pay back the depositors and entrepreneur and responsibility of the bank will be finished after completing the above transformation. The process is shown in chart 2.

Table 1: The PLS banking product and services framework

\begin{tabular}{|c|c|c|c|c|}
\hline Products & $\begin{array}{l}\text { Settlement time } \\
\text { Profit/loss }\end{array}$ & $\begin{array}{l}\text { Type of } \\
\text { contracts }\end{array}$ & Financial hedging & $\begin{array}{c}\text { Mosharaka and Pazireh Certificates } \\
\text { specifications }\end{array}$ \\
\hline $\begin{array}{c}\text { Special } \\
\text { project } \\
\text { (finitude) }\end{array}$ & $\begin{array}{l}\text { Completion of } \\
\text { construction and } \\
\text { selling the } \\
\text { constructed project }\end{array}$ & \multirow[t]{4}{*}{$\begin{array}{c}\text { Jualah } \\
\text { Wakalah } \\
\text { Solh }\end{array}$} & $\begin{array}{l}\text { Insurance of some } \\
\text { portion of the } \\
\text { value of the } \\
\text { projects can be }\end{array}$ & \multirow{4}{*}{$\begin{array}{l}\text { - Anonymity } \\
\text { - Transformable to others } \\
\text { - Transactability in virtual Internet-based } \\
\text { secondary certificate market and on the } \\
\text { bank counter and stock exchange in a } \\
\text { mechanized IT-based state. } \\
\text { - Earning commission from both } \\
\text { transactor parties per transaction. } \\
\text { - Valuation of certificates based on } \\
\text { demand and supply mechanism. } \\
\text { - Transformation possibility of Pazireh } \\
\text { Certificates to shares in endless } \\
\text { projects. } \\
\text { - Decisive final settlement with the last } \\
\text { Mosharaka Certificates owners. } \\
\text { - Customer groups can be private or } \\
\text { governmental, real persons, or legal } \\
\text { entities. }\end{array}$} \\
\hline $\begin{array}{l}\text { Basket of } \\
\text { Projects } \\
\text { (finitude) }\end{array}$ & $\begin{array}{c}\text { Completion of } \\
\text { construction and } \\
\text { selling the } \\
\text { constructed project }\end{array}$ & & $\begin{array}{l}\text { Other insurance } \\
\text { instruments as }\end{array}$ & \\
\hline $\begin{array}{l}\text { Participation } \\
\text { in PLS } \\
\text { branch's } \\
\text { Profit and } \\
\text { loss } \\
\text { (finitude) }\end{array}$ & $\begin{array}{l}\text { At the end of the } \\
\text { fiscal year }\end{array}$ & & $\begin{array}{l}\text { responsibility } \\
\text { insurance, } \\
\text { engineering } \\
\text { insurance, and } \\
\text { accident insurance } \\
\text { have been defined }\end{array}$ & \\
\hline $\begin{array}{l}\text { Endless } \\
\text { projects }\end{array}$ & $\begin{array}{l}\text { Completion of the } \\
\text { construction period } \\
\text { and at the beginning } \\
\text { of the exploitation } \\
\text { period }\end{array}$ & & $\begin{array}{l}\text { in different related } \\
\text { contracts to hedge } \\
\text { the project } \\
\text { execution }\end{array}$ & \\
\hline
\end{tabular}




\section{Chart 2: PLS banking products and process}

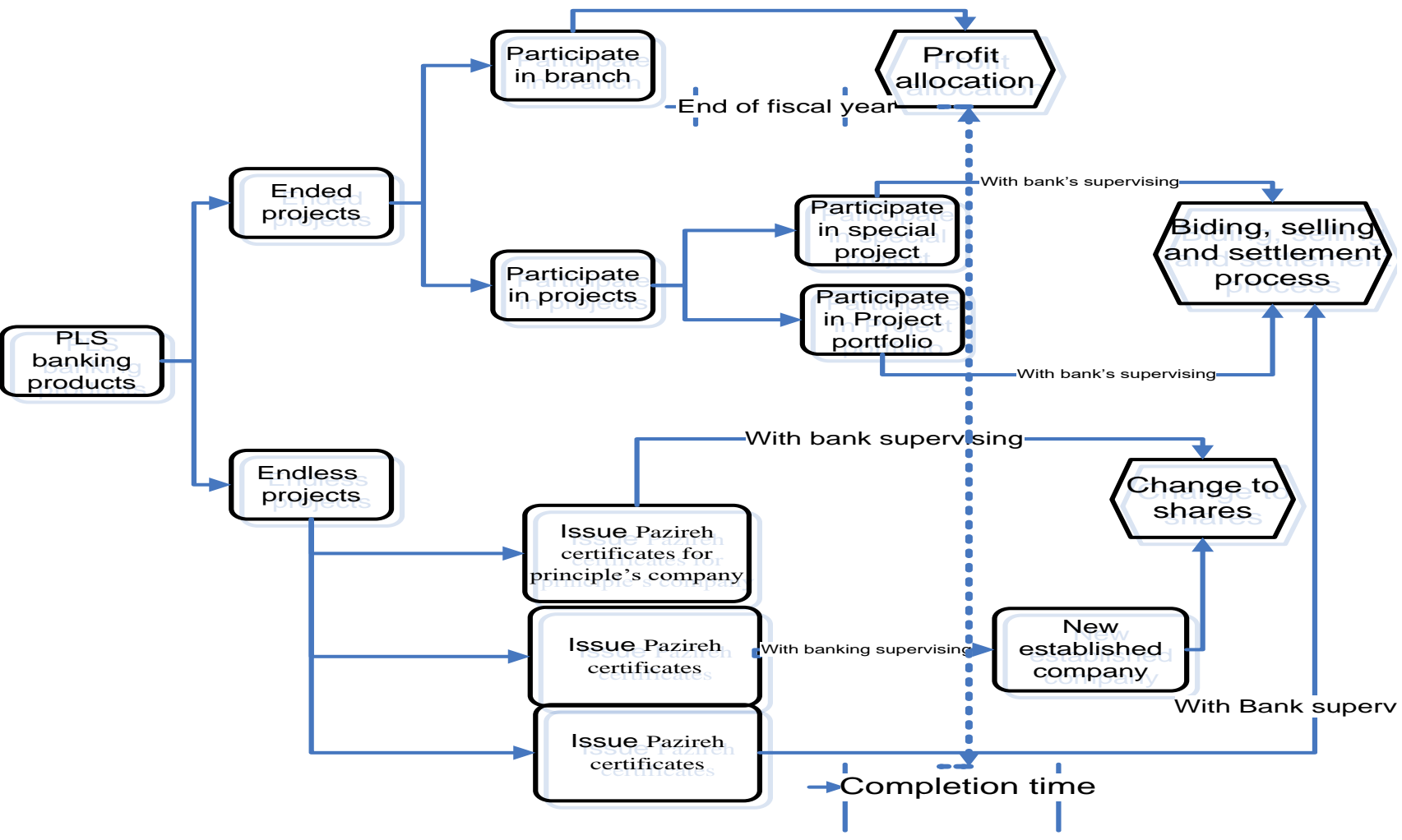

\section{PLS Banking Customers Groups}

According to this banking framework, the customers can be categorized into two groups of depositors and entrepreneurs of investments projects as follows:

$\checkmark$ Depositors: Depositors in PLS banking could be a real person or legal entity and either private or governmental.

$\checkmark$ Entrepreneurs: Entrepreneurs in PLS banking necessarily must be a legal entity/corporation, either private or governmental. Legal entity specification for the entrepreneurs is necessary for auditing financial documents and statements that cause reliable and more transparent calculation for profit or loss calculations.

\section{Islamic Contracts In PLS Banking}

Bank on the basis of Jualah contraction arranges a formal agreement with depositors so that according to depositor opinion, provide partnership in entrepreneur's investment. In the other side, the bank based on Mosharaka contract (based on Civil Participation contraction) will be entered into interaction with the entrepreneur. By this contract, the bank will do as an intermediate entity and gains Haqh-aljualah (wage) from depositors and mobilize financial (deposit) resources entrepreneur. Finally, investment returns portion for depositor will be transferred to the suppliers of the resources (depositors) based on the agreements of the contract. The Solh (peace pact) contract is needful beside of the Jualah contraction as necessary for simplifying Mosharaka and Pazireh Certificates transactions on the internet-based secondary certificate market for depositor approval and her signature.

\section{PLS Banking Instruments}


In PLS banking, the new financial instruments and innovations as Mosharaka and Pazireh Certificates are applied. By PLS banking, the bank increases the efficiency of monetary and financial markets and by issuing Mosharaka and Pazireh Certificates and establishing secondary certificate market and designing Mosharaka Certificate basket/portfolio will play an important role in the mobilization of resources. Performing the mentioned specifications of PLS will facilitate domestic and international customers to enter the PLS-based depositing and investment simply.

The other complement financial instruments will be separated into Mosharaka Certificate basket/portfolio, issuing and applying insurance products for covering probable risks. The relation between risk and return in investment and financial activities and covering the whole customer groups' requirements in view of the risk-acceptability, the classification of the PLS banking products is important. Therefore, for decreasing risk in the PLS banking products, the Certificates can be classified in the following portfolios:

- Mosharaka Certificate portfolio with low risk and low rate of return

- Mosharaka Certificate portfolio with medium risk and a medium rate of return

- Mosharaka Certificate portfolio with high risk and high rate of return

For insurance encouraging and supporting of capital owners and decreasing different risks among them as moral hazard $^{14}$, adverse selection ${ }^{15}$, and asymmetric information, ${ }^{16}$ the bank can establish an organization to provide necessary supports. For avoidance from falling in moral hazard in the side of the capital owners, it is required that a portion of customer's principle of capital be covered by insurance coverage. The coverage may be around $50 \%$ of the deposited capital. This insurance is arbitrary and might be supplied by the bank or other insurance corporations and purchased by depositors

\section{Organization of PLS Banking}

The organizational structure of the PLS banking with paying attention to the above definitions might be designed in the form of PLS banking strategy committee, PLS banking specialist group, PLS department, legal department, project evaluation department, auditing department, financial engineering management department, trustee (Amin) and PLS branch in which the latter is designed to have information, consulting services and cashier sections.

\section{Summary and Conclusions}

As long as the PLS bank as a financial intermediary does not operate as conventional banks and receives wages from depositors for financial services she provides, will not meet bankruptcy in crisis.

As the rate of the benefit of depositors is dependent on the real rate of return of the economy, depositors benefit increases through PLS banking.

In the period of crisis, the entrepreneurs of investment projects are more protected from bankruptcy; consulting, contractors, and constructors industry are not subject to serious financial defeats with PLS banking.

The financial and economic markets meet stability through PLS banking.

Financial innovations of mosharaka and Pazireh Certificates make the bank act as an international portal performing similar jobs to a stock exchange market for the transaction of PLS products Certificates that can easily allocate and reroute resources to investments.

In the PLS banking apart from the bank is either governmental or private, the interest rate is determined by real

\footnotetext{
${ }^{14}$ Moral hazard in insurance market indicates some cases that insured changes his or her behavior after buying insurance policy and with this imagination that instead of supplying losses try to announce more losses or change his/her behavior of paying attention to keep insured property. For example, some of the insured after buying the insurance policy would never care on insured property and this will increase the risk of insured properties.

${ }^{15}$ Adverse selection is a market process that is caused by undesirable results due to asymmetric information between sellers and buyers.

${ }^{16}$ Asymmetric information means one party has got more information than the other in their business.
} 
sector and bank as financial intermediary gets a commission as an attorney or agent of depositors and will transfer the remaining investment return either profit or loss consequences to depositors. Bank would invest collected deposits into the finitude or endless projects based on Mosharaka Contraction as either general or special attorney according to the depositor's desire (for type 1 and 2 products) or bank own choice (for type 3 products) and finally distribute the investment return among the depositors. In this regard, the bank after deducting commission as being attorney or agent will assign the whole benefits to come from investment to owners of monetary resources and do perform her own intermediary function according to compiled instructions.

First, the entrepreneur refers to the PLS branches and offers her proposal to the bank for doing a joint venture. She will be announced the participation conditions and regulations through an information portal designed for PLS banking. The related evaluation fee will be taken from the customers and projects specifications, including proposal, economic, financial, and technical feasibility documents of the project will be taken from the entrepreneur.

Bank after evaluation of the proposal will introduce it to depositors. Depositors by purchasing Mosharaka/Pazireh Certificates allow the bank to use their deposits in participation into the approved project.

In the PLS a trustee (Amin) unit will do supervision on entrepreneur operations on behalf of the bank for watching good performing of the project, executive operations controlling in comparison with announced programs, resources allocation manner and optimized allocation of resources by using key indices and considering the financial statements are duties of Amin.

In PLS banking, the bank will use new financial instruments and innovations of Mosharaka Certificates for finitude projects and Pazireh Certificates for endless projects. Secondary Certificate market in cyberspace for Certificates transactions is established by the bank. The whole operations will be done according to the compiled instructions. The PLS banking organization was designed according to the above definition in the form of committees, units, and departments.

For applying this kind of banking method, it might be performed by establishing a branch inside of the conventional bank. In this case, the whole activities of the PLS banking shall be done alongside to the other conventional branch activities but with separated financial, accounting, organizational and office operations for preserving legal aspects of depositor's rights.

\section{References}

Bahrain Monetary Agency Issues New Islamic Banking Regulations, Vol. XLV No 5, 4 February 2002.

Bidabad, Bijan. (2014). New Operational Islamic Banking System, Volume One, Theoretical Foundations, LAP Lambert Academic Publishing, OmniScriptum GmbH \& Co. KG, ISBN: 978-3-659-54463-7.

Bidabad, Bijan. (2014). New Operational Islamic Banking System, Volume Two, Applicational Issues, LAP Lambert Academic Publishing, OmniScriptum GmbH \& Co. KG, ISBN: 978-3-659-55210-6.

Bidabad, Bijan, Saeed Abdullahi, Mahshid Sherafati. (2016) Enforcement of the Purports of Binding Banking Documents in Rastin Banking - Part I. International Journal of Law and Management, Vol:59, Iss:1.

Bidabad, Bijan, Saeed Abdullahi, Mahshid Sherafati. (2016) Enforcement of the Purports of Binding Banking Documents in Rastin Banking - Part II. International Journal of Law and Management, Vol:59, Iss:2.

Bidabad, Bijan (2018), General Regulatory Framework in Rastin Profit and Loss Sharing Banking (Part IOperational Context). Journal of Business and Finance in Emerging Markets, JBFEM, [S.1.], v. 1, n. 1, p. 1126, May. ISSN 2580-5568. https://doi.org/10.32770/jbfem.vol111-26 http://www.bidabad.com/doc/rastin-regulatory-en-I.pdf

Bidabad, Bijan (2018), General Regulatory Framework in Rastin Profit and Loss Sharing Banking (Part II-Legal 
Groundwork). Journal of Business and Finance in Emerging Markets, JBFEM, JBFEM, [S.1.], v. 1, n. 2, p. 109-126, Nov. ISSN 2580-5568.

https://doi.org/10.32770/jbfem.vol1109-126

http://www.bidabad.com/doc/rastin-regulatory-en-II.pdf

Bidabad, Bijan (2019), General Regulatory Framework in Rastin Profit and Loss Sharing Banking (Part IIIAuxiliary Provisions). Journal of Business and Finance in Emerging Markets, JBFEM, May, Vol 2, No. 1, pp. 51-65. ISSN 2580-5568.

https://doi.org/10.32770/jbfem.vol251-66

http://www.bidabad.com/doc/rastin-regulatory-en-III.pdf

Bijan Bidabad, Mahmoud Allahyarifard. (2019) IT role in fulfillment of Profit \& Loss Sharing (PLS) mechanism. Proceeding of the 3rd International Islamic Banking and Finance Conference, The Monash University, KL, Malaysia, 16-17 November, 2005. International Journal of Islamic Banking and Finance Research, 3(2), 44-59. https://www.cribfb.com/journal/index.php/ijibfr/article/view/274

http://dx.doi.org/10.20193/ijibfr.v3i2.274

http://www.bidabad.com/doc/english-pls-5.pdf

http://www.bidabad.com/doc/pls-it-en.ppt

Bijan Bidabad, (2019) Economic-juristic analysis of usury in consumption and investment loans and contemporary jurisprudence shortages in exploring legislator commandments. Proceeding of the 2nd International Islamic Banking Conference. The Monash University of Malaysia. 9-10 September 2004. Reprinted in: National Interest, Journal of the Center for Strategic Research, Vol. 2, No. 1, winter 2006, pp. 72-90. Tehran, Iran. Republished (revised) in: International Journal of Islamic Business \& Management, 3(2), 1-15.

https://www.cribfb.com/journal/index.php/ijibm/article/view/275

http://www.bidabad.com/doc/reba-en.pdf

Bijan Bidabad, (2019) Non-Usury Bank Corporation (NUBankCo), The Solution to Islamic banking, Proceeding of the 3rd International Islamic Banking and Finance Conference, Monash University, KL, Malaysia, 16-17 November, 2005. International Journal of Shari'ah and Corporate Governance Research, 2(1), 53-66.

https://www.cribfb.com/journal/index.php/ijscgr/article/view/276

http://www.bidabad.com/doc/NUBankCo-en.pdf

Bijan Bidabad, Mahmoud Allahyarifard. (2019) Assets and Liabilities Management in Islamic Banking. Proceeding of the 3rd International Conference on Islamic banking and Finance, Risk Management, Regulation and Supervision, Bidakara, Jakarta, Indonesia, 23-26 February, 2010. pp. 396-413. International Journal of Islamic Banking and Finance Research, 3(2), 32-43.

https://www.cribfb.com/journal/index.php/ijibfr/article/view/272

http://www.bidabad.com/doc/alm-english.pdf

Bidabad, Bijan, (2017) Money Laundering Detection System (MLD), A Complementary System of Rastin Banking, Journal of Money Laundering Control, Vol. 20 Issue: 4, pp. 354-366.

https://doi.org/10.1108/JMLC-04-2016-0016

http://www.bidabad.com/doc/mld-paper-en.pdf

Bidabad, Bijan, (2014) Joint Stock Company with Variable Capital (JSCVC), International Journal of Law and Management (IJLMA), Emerald Group Publishing Limited, Vol. 56, Iss: 4, pp.302 - 310.

http://dx.doi.org/10.1108/IJLMA-09-2012-0031

http://www.bidabad.com/doc/vjsc-paper-en.pdf

Bijan Bidabad, (2019) Rastin Certificate Market (RCM), Complementary System of Rastin Banking, 2013. International Journal of Islamic Business \& Management, 3(1), 35-43.

https://www.cribfb.com/journal/index.php/ijibm/article/view/260

http://www.bidabad.com/doc/rastin-bank-rcm-en.pdf

Bidabad, Bijan, (2013) Rastin Profit and Loss Sharing (PLS) Base System. Journal of Islamic Economics, Banking 
and Finance, pp. 32-57, Vol. 9 No. 4, Oct-Dec. http://ibtra.com/pdf/journal/v9_n4_article2.pdf http://www.bidabad.com/doc/pls-base-en.pdf

Bidabad, Bijan, (2016) Joalah Finance Sharing (JFS). Journal of Islamic Economics, Banking and Finance, Volume12, No. 1, January-March, pp. 33-48. http://www.bidabad.com/doc/jfs-paper-en.pdf http://ibtra.com/pdf/journal/v12_n1_article2.pdf

Bidabad, Bijan, (2014) Mudarebah Financial Sharing (MFS). Journal of Islamic Economics, Banking and Finance, JIEBF, Volume - 10, Number - 1, January - April 2014, pp. 56-68.

http://www.bidabad.com/doc/mfs-paper-en.pdf http://ibtra.com/pdf/journal/v10_n1_article3.pdf

Bidabad, Bijan, (2019) Installment Financial Sharing (IFS): A Financial Subsystem of Rastin PLS Banking. International Journal of Islamic Banking and Finance Research, 3(1), 28-42. https://www.cribfb.com/journal/index.php/ijibfr/article/view/267 http://www.bidabad.com/doc/ifs-paper-en.pdf

Bidabad, Bijan, (2014) Rent Financial Sharing (RFS). Journal of Islamic Economics, Banking and Finance, Vol. 10 No. 2, pp.: 38-53, April-June. http://www.bidabad.com/doc/rfs-paper-en.pdf http://ibtra.com/pdf/journal/v10_n2_article2.pdf

Bidabad, Bijan, (2019) Bail Financial Sharing (BFS): A Financial Subsystem of Rastin PLS Banking. Bank Melli Iran, Tehran, Iran, 2014. International Journal of Islamic Banking and Finance Research, 3(1), 21-27. https://www.cribfb.com/journal/index.php/ijibfr/article/view/266 http://www.bidabad.com/doc/bfs-paper-en.pdf

Bidabad, Bijan, (2015) Rastin Personal Security (RPS). Journal of Islamic Economics, Banking and Finance, JIEBF, Volume - 11, Number - 2, April-June, pp. 47-61. http://www.bidabad.com/doc/rps-paper-en.pdf http://ibtra.com/pdf/journal/v11_n2_article3.pdf

Bidabad, Bijan, (2015) Rastin Social Takaful (RST). Journal of Islamic Economics, Banking and Finance, JIEBF, Volume - 11, Number - 1, January - March, pp.: 13-23. http://www.bidabad.com/doc/rst-paper-en.pdf http://ibtra.com/pdf/journal/v11_n1_article1.pdf

Bidabad, Bijan, (2019) Rastin Crowdfunding (RCF): A Financial Subsystem of Rastin Banking. Bank Melli Iran, Tehran, 2014. International Journal of Islamic Banking and Finance Research, 3(1), 13-20. https://www.cribfb.com/journal/index.php/ijibfr/article/view/265 http://www.bidabad.com/doc/rcf-paper-en.pdf

Bidabad, Bijan, (2019) Rastin Group Funding (RGF): A Financial Subsystem of Rastin Banking. Bank Melli Iran, Tehran, 2014. International Journal of Islamic Banking and Finance Research, 3(1), 43-48. https://www.cribfb.com/journal/index.php/ijibfr/article/view/268 http://www.bidabad.com/doc/rgf-paper-en.pdf

Bidabad, Bijan, (2015) Serial Commitments Clearance (SCC) in Rastin Banking. International Journal of Law and Management (IJLMA), Vol. 57, Iss: 6, pp. 600-609. http://dx.doi.org/10.1108/IJLMA-02-2015-0007 http://www.bidabad.com/doc/scc-paper-en.pdf

Bidabad, Bijan, (2019) Rastin Swap Deposit (RSD): A Financial Account of Rastin Banking. Tehran, 2015. International Journal of Islamic Banking and Finance Research, 3(2), 17-23. 
https://www.cribfb.com/journal/index.php/ijibfr/article/view/270

http://www.bidabad.com/doc/rsd-paper-en.pdf

Bidabad, Bijan, (2019) Rastin Swap Card (RSC): A Financial Instrument of Rastin Banking. Tehran, 2015. International Journal of Islamic Banking and Finance Research, 3(2), 24-31.

https://www.cribfb.com/journal/index.php/ijibfr/article/view/271

http://www.bidabad.com/doc/rsc-paper-en.pdf

http://dx.doi.org/10.20193/ijibfr.v3i2.271

Bidabad, Bijan, Mahmoud Allahyarifard, (2019) Interbank Withdrawal Protocol (IWP), Complementary System of Rastin Banking 2013. International Journal of Islamic Business \& Management, 3(1), 30-34.

https://www.cribfb.com/journal/index.php/ijibm/article/view/259

http://www.bidabad.com/doc/iwp-paper-en.pdf

Bidabad, Bijan, (2019) Change Management of Banking System at National Level by Rastin Banking (Knowledge Management, Empowerment, Prune and Graft, and Apprenticeship), presented at the 10th International Conference on Economics and Management, Islamic Azad University, Rasht, Iran, 2017. Review of Behavioral Aspect in Organizations and Society, 2019, 1(1), 11. Review of Behavioral Aspect in Organizations and Society, 1(1), 57-70 . https://doi.org/10.32770/rbaos.vol157-70 http://www.bidabad.com/doc/change-banking-en.pdf http://www.bidabad.com/doc/change-banking-en.pptx

Bidabad, Bijan, Azarang Amirostovar, Mahshid Sherafati, (2017) Financial Transparency, Corporate Governance and Information Disclosure of the Entrepreneur's Corporation in Rastin Banking. International Journal of Law and Management (IJLMA), Vol:59, Iss:5, pp.636-651, 2017.

https://doi.org/10.1108/IJLMA-01-2016-0003

Bidabad, Bijan, Mahshid Sherafati, (2016) Operational Ethical Banking in Rastin Banking (Professional Ethics, Audit, Inspection, Control, Monitoring and Preservation). International Journal of Law and Management (IJLMA), Vol: 58, Iss: 4, 2016, pp. 416-443. http://dx.doi.org/10.1108/IJLMA-07-2015-0037 http://www.bidabad.com/doc/rastin-ethic-banking-en.pdf

Rammal, H. G. (2003) 'Mudaraba in Islamic finance: Entrepreneurs and application', Business Journal For Entrepreneurs, Vol.4, pp.105-112. http://www.westga.edu/ bquest/2004/musharaka.htm

Hussain Gulzar Rammal and Ralf Zurbruegg, "Awareness of Islamic banking products among Muslims: The case of Australia", Journal of Financial Services Marketing (2007) 12, 65-74, Doi:10.1057/palgrave.fsm.4760060, http://www.palgrave-journals.com/fsm/journal/v12/n1/full/4760060a.html\#bib24

Humayon A. Dar and John R. Presley (2000), "Lack of Profit Loss Sharing in Islamic Banking: Management and Control Imbalances", Loughborough University,Department of Economics, Economic Research Paper No. 00/24, http://www.lut.ac.uk/departments/ec/Reasearchpapers/2000/00-24/erp00-24.pdf

Chong, B.S., Liu, M.H, 2007, "Islamic Banking: Interest-Free or Interest-Based", http://www.efmaefm.org/0EFMAMEETINGS/EFMA\%20ANNUAL\%20MEETINGS/2007Vienna/Papers/0019.pdf

Khan, M.S., 1986. Islamic interest-free banking. IMF Staff Papers 33, 1-27

World Bank, 2006. Country brief report: Malaysia.

http://siteresources.worldbank.org/INTEAPHALFYEARLYUPDATE/Resources/550192-

1143237132157/malaysia-March06.pdf

• اداره تحقيقات و برنامهريزي بانك ملي ايران/طرح مطالعاني و كاربردي بانكداري مشاركت در سود و زيان)، 1387-1386. 
الهياري فرد، محمود (1384)، خدمات بانكداري الكترونيك و نيازهاي اجر ائي آن در مقايسه تطبيقي هزينه عملياتي خدمات مختلف بانكي،

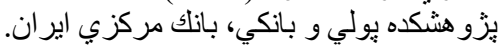

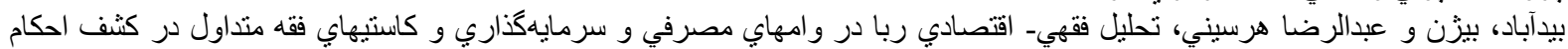

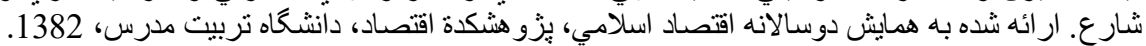
http://www.bidabad.com/doc/reba9.html

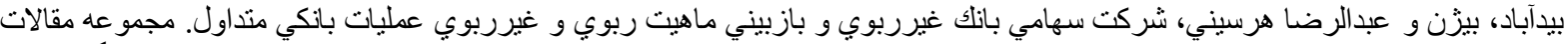

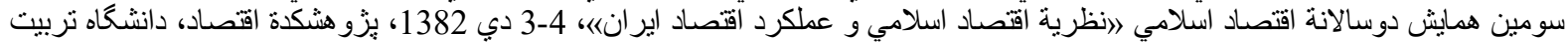

http://www.bidabad.com/doc/sherkat6.htm

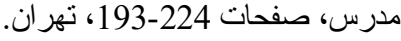

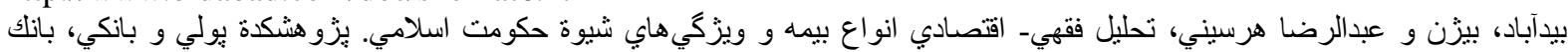

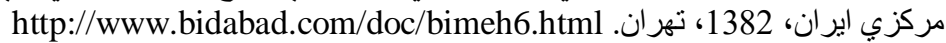

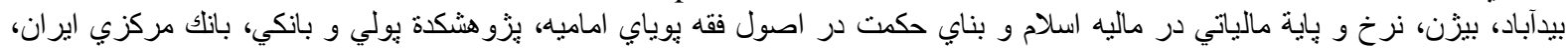

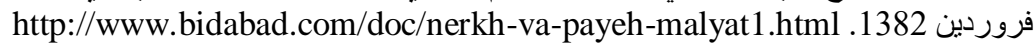
بيدآباد، بيزن و محمود الهياري فرد، بستر هاى نرمافزارى تجارت و بانكدارى الكترونيك در ايران.

http://www.bidabad.com/doc/narm-ebank.html http://www.bidabad.com/doc/narm-ebank-revised.html

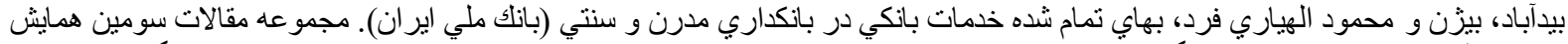

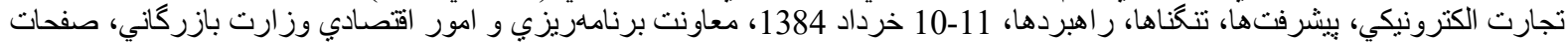

hوttp://www.bidabad.com/doc/baha-ebank.html

1383 وير ايش وير ايش 1385 وير

hوttp://www.bidabad.com/doc/baha-ebank-update-1385.pdf

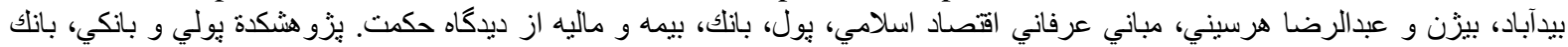

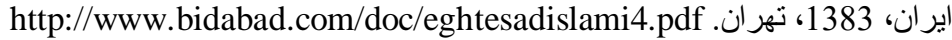

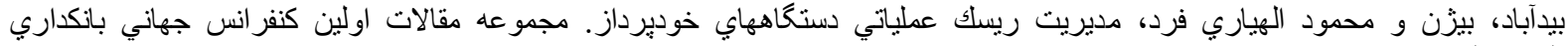

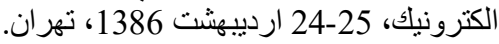

http://www.bidabad.com/doc/risk_management_in_e_banking.pdf

http://www.bidabad.com/doc/alm-farsi.pdf

$$
\text { بيدآباد، بيزن و محمود الهياري فرد، مديريت دار ائي و بدهي (ALM) در بانكداري اسلامي. }
$$

\section{Copyrights}

Copyright for this article is retained by the author(s), with first publication rights granted to the journal. This is an open-access article distributed under the terms and conditions of the Creative Commons Attribution license (http://creativecommons.org/licenses/by/4.0/). 